Таблица 1.

Бечмаркетинг «VEON» и конкурентных приложений

\begin{tabular}{|c|c|c|c|c|c|}
\hline $\begin{array}{c}\text { Название } \\
\text { приложения }\end{array}$ & $\begin{array}{c}\text { Количество } \\
\text { скачиваний на } \\
2017 \text { год }\end{array}$ & $\begin{array}{c}\text { Дата } \\
\text { основания }\end{array}$ & $\begin{array}{c}\text { Участники } \\
\text { группыв ВК }\end{array}$ & $\begin{array}{c}\text { Участники } \\
\text { группы в } \\
\text { Facebook }\end{array}$ & $\begin{array}{c}\text { Подписчики } \\
\text { в Instagram }\end{array}$ \\
\hline Viber & $600 \mathrm{млн}$ & 2010 & 283397 & 9446449 & 242000 \\
\hline Wechat & $900 \mathrm{млн}$ & 2011 & 10243 & 3517310 & - \\
\hline Telegram & $100 \mathrm{млн}$ & 2013 & 60177 & 67831 & 444000 \\
\hline Veon & $5 \mathrm{MлH}$ & 2017 & 964 & 441809 & 71600 \\
\hline
\end{tabular}

«VEON» занимает последнюю строчку среди рекламы своего продукта в соц. сетях, но можно говорить о том, что такое явление присуще в силу недавнего создания приложения.

Реклама «ВымпелКом» закладывается на трёх уровнях: федеральном уровне (рекламные ролики на телевидении), макрорегиональном уровне (радиореклама) и региональном (размещение наружной рекламы, проведение региональных рекламных акций). Сильной стороной рекламного продвижения компании «ВымпелКом» является его креативность, интересное содержание и яркость.

В России ускоренные темпы роста стали возможны благодаря сфере мобильной связи, которая после двухлетнего спада показала положительную динамику. Услуги фиксированной телефонной связи, наоборот, оказали негативное влияние на динамику рынка (за 2017 год 2,7 млн абонентов отказались от фиксированной связи) [5].

Из проведенного анализа можно сделать вывод, что телекоммуникационный сектор - одно из важнейших направлений для развития экономики. Сегодняшние операторы работают сразу в нескольких сферах рынка, предоставляя и интернет, и телевидение, и аксессуары для мобильных устройств, и многое другое. С учетом дальнейшей информатизации экономики digital сфера, и рынок телекоммуникационных технологий в частности, в ближайшие 5 лет будет развиваться все более активно растущими темпами.

$$
* * *
$$

1. Андреева М. «ВымпелКом» попал под рыночный тренд от 10.11.2017/ Сайт «Comnews» [Электронный pecypc]. - Режим доступа: http://www.comnews.ru/content/110419.

2. Беквит Гарри. Продавая незримое: Руководство по современному маркетингу услуг / Гарри Беквит; Пер. с англ. - М. : Альпина Паблишер, 2017. - 220с.

3. Гладченко A. 10 способов стимулирования сбыта / Сайт «Деловой портал b2bis» [Электронный ресурс]. - Режим доступа: http://b2bis.ru/statya/10-sposobov-stimulirovaniya-sbyta.

4. Каримов М. К. Услуги в сфере телекоммуникации и их продвижение / Молодой ученый, №13, 2015 C.35-37.

5. Отчет аналитического агентства «ТМТ Консалтинг» за 2017 год./ Сайт «ТМТ Консалтинг» [Электронный ресурс]. - Режим доступа: http://tmt-consulting.ru/wp-content/uploads/2017/12/TMTтелеком-2017.pdf

\title{
Юнусов И.А. \\ Влияние привлечения ПИИ на обеспечение устойчивого развития в экономике РФ
}

doi:10.18411/lj-31-03-2018-77

КНИТУ-КАИ им. А.Н. Туполева

idsp: 000001:lj-31-03-2018-77

Устойчивое развитие любой экономики требует активных финансовых вложений. Однако санкции введенные в 2014 г. усиленно противодействуют обеспечению устойчивому развитию. К сожалению, на сегодняшний день, нельзя утверждать что ситуация изменится в лучшую сторону. 
Таблица 1

Основные макроэкономические показатели. [1, с.11]

\begin{tabular}{|c|c|c|c|c|c|c|}
\hline & 2011 & 2012 & 2013 & 2014 & 2015 & 2016 \\
\hline Валовой внутренний продуктмлрд. руб. & 60282,5 & 68163,9 & 73133,9 & 79199,7 & 83232,6 & 86043,6 \\
\hline Валовое накопление млрд. руб. & 14735,9 & 16730,2 & 16915,8 & 17614,6 & 18622,1 & 20132,1 \\
\hline $\begin{array}{c}\text { Инвестиции в основной капитал млрд. } \\
\text { руб. }\end{array}$ & 11035,7 & 12586,1 & 13450,2 & 13902,6 & 13897,2 & 14639,8 \\
\hline
\end{tabular}

Как видно из данных таблицы 1 до 2014 г. наблюдался незначительный рост ВВП в постоянных ценах. В 2011 г. рост ВВП к предыдущему периоду составил 4,3\%, 2012г. $3,7 \%$, в 2013 г. - 1,8\%, 2014 г. - 0,7\%. Такой незначительный рост связан с введением санкций, резким увеличением инфляции, падением курса рубля по отношению к иностранным валютам, снижением цен на нефть. В дальнейшем наблюдается падение ВВП РФ в постоянных ценах:

$$
\begin{aligned}
& 2015 \text { г. }-2,8 \% \\
& 2016 \text { г. }-0,2 \%
\end{aligned}
$$

Анализируя инвестиции в основной капитал, то после введения санкций снижение опережало падение ВВП РФ. К примеру, в 2014 г. инвестиции в основной капитал в сопоставимых ценах снижение составило 1,46\%, в 2015 г. - 10,1\%, в 2016 г. - 0,9\%.

По данным ЦБ РФ, в 2016 г. наблюдался негативное сальдо прямых инвестиций.

Таблища 2

Динамика прямых инвестиций РФ. (сальдо операџий платежного баланса Российской Федерачии; миллионов долларов США) [1, с.13]

\begin{tabular}{|c|c|c|c|c|c|c|c|}
\hline & 2010 & 2011 & 2012 & 2013 & 2014 & 2015 & 2016 \\
\hline Прямые инвестиции & 9448 & 11767 & -1766 & 17288 & 35051 & 15232 & -10225 \\
\hline За границу & 52616 & 66851 & 48822 & 86507 & 57082 & 22085 & 22314 \\
\hline В Россию & 43168 & 55084 & 50588 & 69219 & 22031 & 6853 & 32539 \\
\hline
\end{tabular}

В 2017 г. наблюдалось некоторое оживление в привлечении прямых инвестиций. По состоянию на 1.07.2017 г. сальдо прямых инвестиций составило 39988 млн. долл. США (рисунок 1).

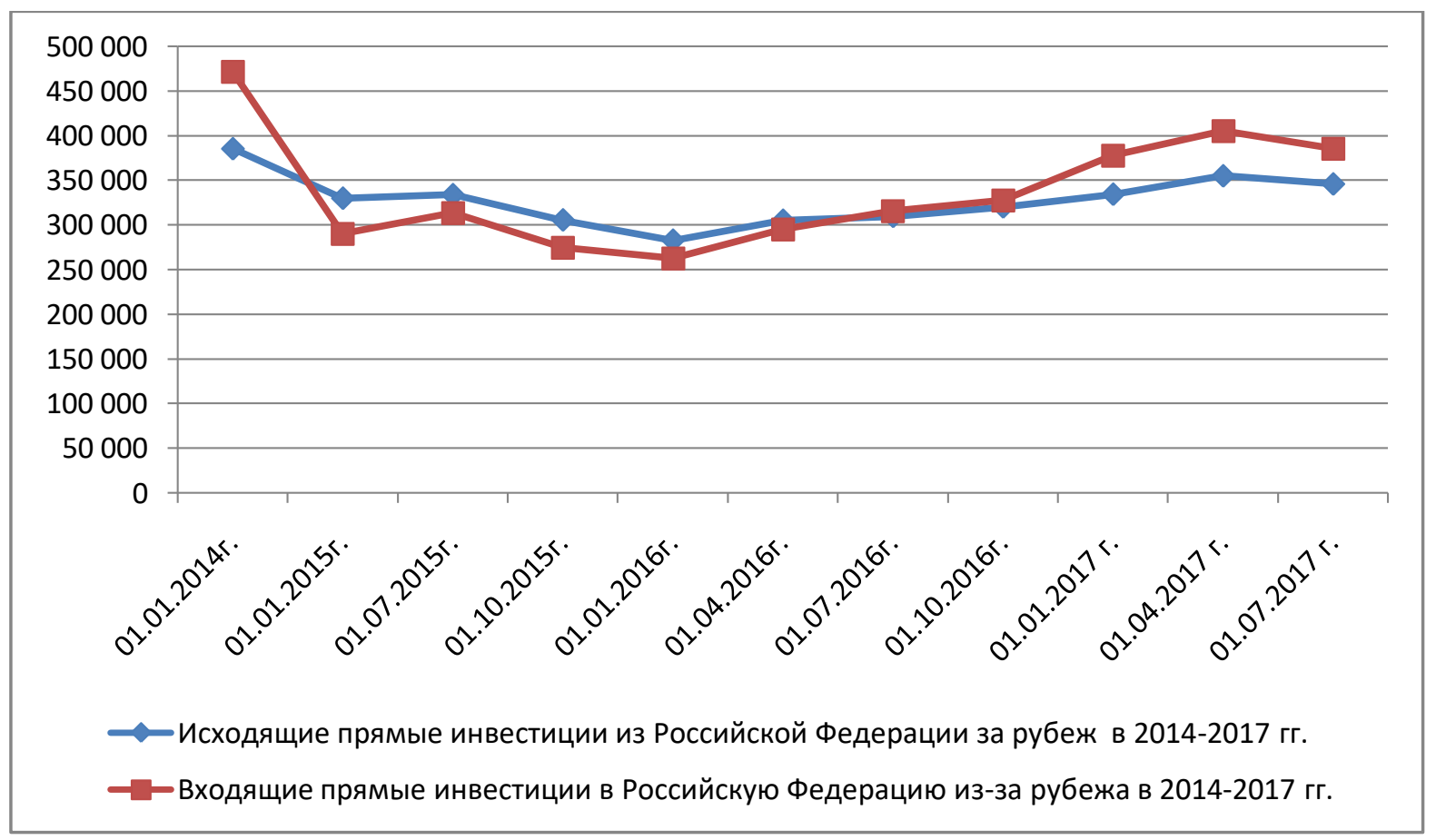

Рисунок 1. Сравнительный анализ входящฺих и исходящих прямых инвестищий РФ 2014-2017 2.г.[10] 
После введённых санкций наблюдалось резкое снижение иностранных инвестиций в экономику РФ. За 2014 г. прямые инвестиции снизились в 1.6 раза. По данным ЦБ РФ по состоянию на 1.07.2017 г. ПИИ достигли показателя 385760 млн. долл. США. Однако этот показатель не достиг уровня 1.01.2014 г. (471474 млн. долл. США).

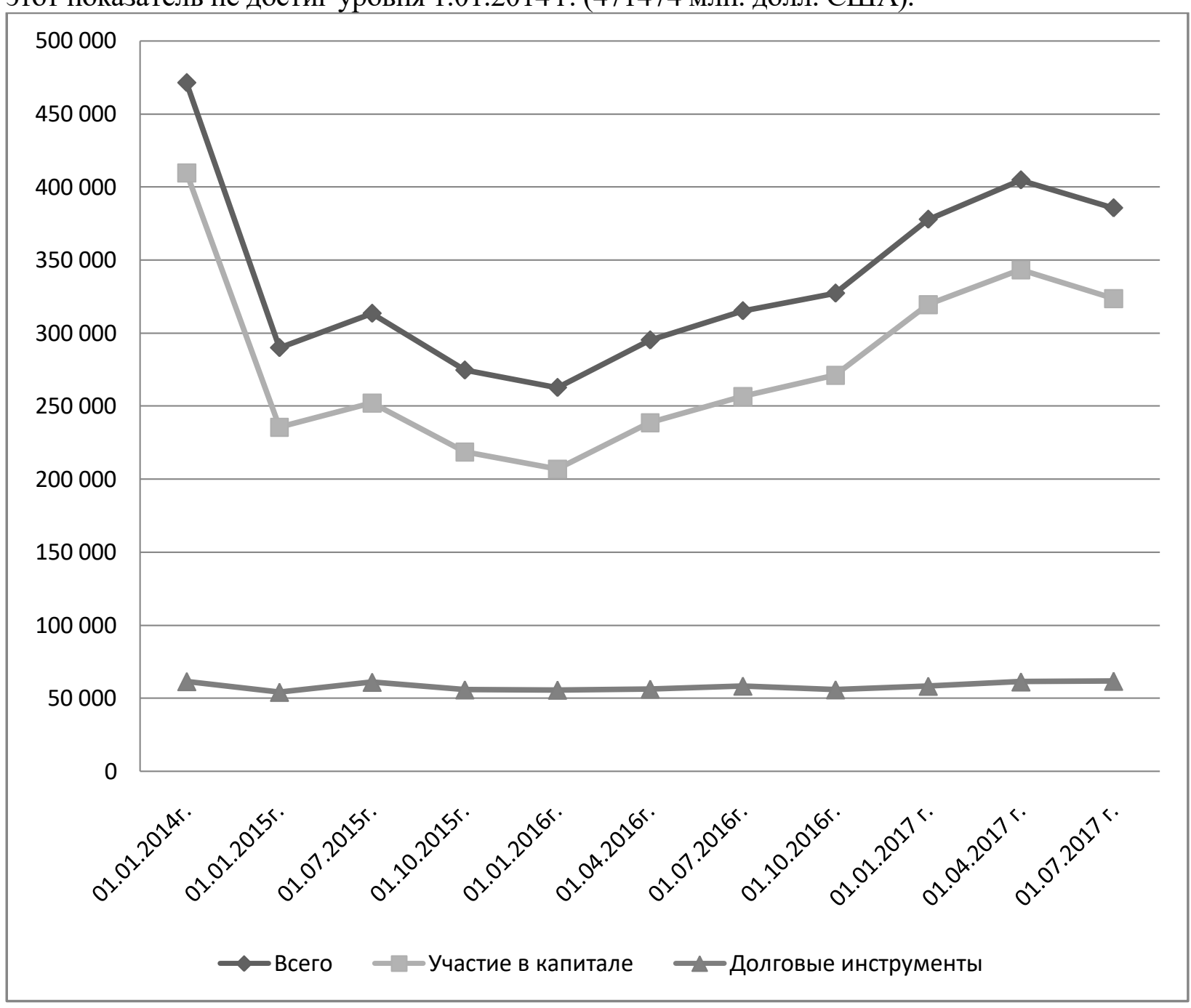

Рисунок 2. Прямье инвестищчи в Российскую Федерацию из-за рубежа: остатки по видам экономической деятельности (млн. долл. США) [10]

Проанализировав структуру ПИИ, можно сделать вывод о том, что основная доля поступления ПИИ является участие в капитале (рисунок 2).

Несмотря на заверения официальных лиц, введение санкций негативно повлияло на экономику РФ. Среди факторов отрицательно влияющих на привлечения инвестиций в экономику РФ можно выделить:

- отток капитала из экономики РФ

- санкции против экономики РФ

- заморозка накопительной части пенсионных отчислений

- снижение доли прибыльных организаций

- закредитованность российских предприятий

- низкая производительность труда

Несмотря на оптимистические данные по экономической ситуации в РФ, пока утверждать, стоит ожидать оживления инвестиций в основной капитал в ближайшее время. Об этом свидетельствует то, что с 2014 г. по настоящее время правительство РФ реализует программу заморозки накопительной части пенсионных отчислений. 
Пенсионные накопления являются, как это принято называть, являются «длинными деньгами». Иначе говоря, пенсионные отчисления являются одним из источников инвестирования в основной капитал. Кроме того, в экономике РФ доминирует спекулятивный капитал. Об этом свидетельствует то, что основными иностранными инвесторами выступают «оффшорные» государства.

В целом, стоит отметить, что проблема привлечения средств в целях инвестирования в основной капитал это системная проблема и решить еще при нынешней экономической политике государства не представляется возможном.

$$
* * *
$$

1. Инвестиции в России. 2017: Стат.сб./ Росстат. - М., 2017. - 188 с

2. Россия в цифрах. 2017: Крат.стат.сб./Росстат - М., 2017 - 511 с.

3. Российский статистический ежегодник. 2017: Стат.сб./Росстат. - М., 2017 - 686 с.

4. Мониторинг экономической ситуации в России: тенденции и вызовы социально-экономического развития. 2017. № 22 (60). Декабрь / Бурдяк А., Гришина Е., Зайцев Ю., Клячко Т., Кнобель А., Плескачев Ю., Пономарев Ю., Токарева Г. Под ред. Гуревича В.С., Дробышевского С.М., Кадочникова П.А., Колесникова А.В., Мау В.А., Синельникова-Мурылева С.Г.; Институт экономической политики имени Е.Т. Гайдара, Российская академия народного хозяйства и государственной службы при Президенте Российской Федерации. 20 с.№ 22(60) Декабрь 2017 г.

5. Мониторинг взаимных инвестиций в странах СНГ - 2017. - СПб.: ЦИИ ЕАБР, 2017. -60 с.

6. Юнусов Л.А. Теория верификации прямых инвестиций в условиях экономического кризиса в России. Журнал «Проблемысовременнойэкономики» 2009 г., №1 с. 26-35

7. Doing Business 2017 Equal Opportunity for All. International Bank for Reconstruction and Development / The World Bank 1818 H Street NW, Washington DC 20433

8. www.ra-national.ru

9. http://www.roskazna.ru/

10. http://www.cbr.ru

11. http://www.gks.ru 